\section{Política energética e agentes científicos: o caso das pesquisas em células a combustível no Brasil*}

Recebido: 26.09 .13

Aprovado: 24.05.14
Thales Novaes de Andrade

\& Bruno Rossi Lorenzi**

Resumo: Este artigo tem como objetivo fazer uma análise das dimensões políticas e sociais das pesquisas em células a combustível e uso energético do hidrogênio no Brasil. Esta pesquisa é um estudo de caso sobre o Centro Nacional de Referência em Energia do Hidrogênio (Ceneh), centro público de pesquisa e consulta em tecnologias relacionadas ao hidrogênio e células a combustível. Como referencial teórico, partimos da sociologia da ciência, em especial a Teoria Ator-Rede de Bruno Latour e Michel Callon, com a qual pudemos identificar os diversos atores sociais envolvidos nas pesquisas nesta área, suas ações, relações e tensões, assim como o panorama social e político em âmbito nacional e internacional relacionado às células à combustível.

Palavras-chave: células a combustível, hidrogênio, Ceneh, sociologia da ciência.

\section{Introdução}

$\mathrm{H}$ oje em dia presenciamos um aumento das preocupações com o meio ambiente, o aquecimento global e a busca de desenvolvimento sustentável nas agendas políticas da maioria das nações. Um dos maiores obstáculos ao desenvolvimento sustentável nos países industrializados é o uso do petróleo como principal fonte energética. Por essas e outras razões, muitos países, incluindo o Brasil, têm buscado novas alternativas energéticas.

A maior parte da matriz energética brasileira (mais de 60\%) provém de combustíveis fósseis, sendo o petróleo a principal fonte de energia. O uso dos derivados do petróleo responde por cerca de $42 \%$ de nossa matriz, e o setor veicular é responsável por cerca de 50\% deste total (MME, 2010). Porém, este setor é um dos principais aliados do uso das células a combustíveis e do hidrogênio. Este, por ser um elemento livre de carbono quando utilizado para fins energéticos através das chamadas células a combustível (dispositivos eletroquímicos que convertem o hidrogênio em eletricidade), não produz tantos resíduos nocivos ao meio ambiente. Além disso, uma grande vantagem do hidrogênio é que ele pode ser obtido através de inúmeras fontes, desde fontes fósseis tradicionais, como petróleo e gás natural, até fontes renováveis (até mesmo da água), na qual a emissão de gases de efeito estufa é menor.

\author{
* Este artigo \\ traz resultados \\ da pesquisa de \\ mestrado intitulada \\ "Em busca de \\ alternativas \\ energéticas: \\ estudo sobre as \\ pesquisas em células \\ combustiveis no \\ Brasil" (Lorenzi, \\ 2012), defendida \\ no Programa de \\ Pós-graduação em \\ Ciência, Tecnologia \\ e Sociedade \\ (PPGCTS) da UFSCar, \\ São Carlos, com \\ financiamento da \\ Fapesp.
}

\footnotetext{
** Thales Novaes de Andrade é docente do Departamento de Ciências Sociais da UFSCar.<thales@ sigmanet.com.br>. Bruno Rossi Lorenzi é mestre pelo Programa de Pós-Graduação em Ciência, Tecnologia e Sociedade (PPGCTS) da UFSCar. <brunolorenzi@ gmail.com>
} 
Apesar de não ser uma fonte primária de energia, o hidrogênio pode ser utilizado como forma de armazenamento de energia, bem como viabilizar fontes alternativas de geração renováveis, como hidrelétrica, solar, eólica etc.

Além de contribuir para uma geração elétrica mais distribuída, as células a combustível também podem ser utilizadas em automóveis. O setor veicular é um dos mais cotados para a utilização dessa tecnologia nos próximos anos. Carros movidos a hidrogênio não emitem nenhum poluente ou gás de efeito estufa, além do fato de as células a combustível $(\mathrm{CaC})$ serem muito mais eficientes e silenciosas do que os motores à combustão. Obtido através de fontes renováveis, que as próprias células a combustível tendem a baratear, o hidrogênio é uma alternativa técnica para substituir em grande escala o uso de derivados de petróleo no setor veicular (Silva, 1991).

O desenvolvimento das células a combustível está acelerado e de certa forma bastante adiantado na maior parte dos países desenvolvidos, onde já se cogita inserir o hidrogênio na matriz energética de maneira significativa nas próximas décadas. O Brasil também faz parte de organizações mundiais para a implantação da economia do hidrogênio, a exemplo do International Partnership for Hydrogen Economy (Iphe), e possui algumas políticas voltadas para a pesquisa e o desenvolvimento das células a combustível e o hidrogênio, com destaque para o Programa de Ciência, Tecnologia e Inovação para a Economia do Hidrogênio (ProH2), do Ministério de Ciência e Tecnologia, e do Roteiro Brasileiro para a Estruturação da Economia do Hidrogênio, do Ministério de Minas e Energia.

Segundo a Teoria do Ator-Rede, desenvolvida por Bruno Latour e Michel Callon, a viabilidade de um artefato tecnológico depende da articulação de seus diversos componentes. À medida que eles se fecham e se estabilizam, cria-se uma caixa-preta (Latour, 2000). No caso das células a combustível no Brasil, o que tem impedido sua transformação em caixa-preta? A falta de uma agenda política definida? A instabilidade dos agentes científicos nacionais? Quais fatores tem contribuído mais decisivamente para sua consolidação como artefato tecnocientífico?

Este artigo tem como objetivo fazer uma análise das dimensões políticas e sociais das pesquisas em células a combustível e da utilização energética do hidrogênio no Brasil. Trata-se de um estudo de caso sobre o Centro Nacional de Referência em Energia do Hidrogênio (Ceneh), um centro público de pesquisa e consulta em tecnologias relacionadas ao hidrogênio e às células a combustível.

Por meio da pesquisa de campo, feita através de consulta a fontes secundárias e entrevistas semiestruturadas com pesquisadores do centro, pudemos constatar diversos atores sociais relacionados às pesquisas nesta área, suas ações, relações e 
tensões, assim como um panorama da situação tecnológica e política das pesquisas e do desenvolvimento do uso energético do hidrogênio nas redes articuladas pelo Ceneh. Nosso interesse aqui consiste em apontar as controvérsias e negociações presentes no estabelecimento da agenda de pesquisa em células a combustível e tentar explicar o estado em que a área se encontra atualmente.

\section{Teoria Ator-Rede: controvérsias e negociações}

A pesquisa baseou-se na Teoria Ator-Rede desenvolvida por Latour. No início da década de 1970, Latour e Woolgar (1997) iniciam um novo tipo de pesquisa, a saber, a etnografia de laboratório.

Ao lamentar a atenção insuficiente dada às práticas científicas pelos pesquisadores das ciências humanas, o autor pretendeu fazer um estudo da ciência e da construção dos fatos científicos ao molde etnográfico/etnológico usado há muito tempo pelos antropólogos para o estudo das sociedades "primitivas", mas pouco usado para estudar a própria sociedade ocidental, principalmente seu cerne ontológico: a ciência. Esta sempre era vista como posicionada em um altar, protegida de toda crítica sobre suas práticas pela epistemologia - que concebe a ciência como forma de conhecimento imune às disputas e práticas micro e macrossociais presentes em todas as demais esferas sociais.

Ao ler a literatura dos antropólogos e ao falar com eles, percebi seu cientificismo. Eles estudavam outras culturas e outras práticas com um respeito meticuloso, mas com um fundo de ciência. Perguntei-me então o que dizer do discurso científico se ele fosse estudado com o cuidado que os etnógrafos têm quando estudam as culturas, as sociedades e os discursos pré, para ou extracientíficos. A "dimensão cognitiva" não estaria, aí também, amplamente exagerada? (Latour \& Woolgar, 1997: 12-13, destaques dos autores).

O Programa Forte de David Bloor (1998) inovou ao colocar em relação de simetria tanto o erro quanto o sucesso. Os mesmos tipos de causa deveriam explicar tanto o sucesso como o fracasso. Para Latour e Woolgar (1997), isso deveria ser levado a sério na investigação da produção científica, trazendo a sociedade da margem para o centro da produção científica. O autor também inova por trazer uma nova relação de simetria: natureza $\leftrightarrow$ sociedade. Para Latour, uma não prevalece sobre a outra e ambas devem ser tratadas nos mesmos termos.

Cumpre não somente tratar nos mesmos termos os vencedores e os vencidos da história das ciências, mas também tratar igualmente e nos mesmos termos a natureza e a sociedade. Não pode- 
mos achar que a primeira é dura como ferro, de modo a explicar a segunda; não podemos acreditar bravamente nas classes sociais para melhor duvidar da física [...]. O trabalho de campo que aqui apresentamos é, por conseguinte, duas vezes simétrico: aplica-se ao verdadeiro e ao falso, esforça-se por reelaborar a construção da natureza e da sociedade (Latour \& Woolgar, 1997: 24).

Latour e Woolgar (1997) enfatizam o caráter antiepistemológico da metalinguagem a ser utilizada em seu trabalho, voltando sua atenção à prática: as maneiras, a linguagem, os instrumentos, as estratégias utilizadas pelos cientistas para promoverem suas teorias e refutarem as de seus concorrentes. Enfim, percebem os fatos científicos como construção a caminhar lentamente rumo a uma estabilização por meio da eliminação de teses e cientistas concorrentes, e da aceitação por parte da comunidade científica, até se tornar um "fato inquestionável".

Os autores ainda atribuem à sua própria prática o mesmo valor que atribuem à prática dos cientistas estudados. Para eles, não há diferença: ambas são práticas científicas e igualmente questionáveis. Enfatizam a necessidade formulada por Bloor (1998) de sempre se aplicar essa reflexividade às ciências humanas, para não se correr o risco de se contradizer ao demonstrar uma prática ou um modelo, nem de ser arrogante atribuindo a si próprio uma natureza ou confiabilidade diferente da do objeto estudado, sobretudo quando o objeto a ser estudado é a própria ciência pela ciência.

Em outro livro, Latour (1994) trata da visão de natureza da ciência moderna. Segundo ele, os povos modernos veem a natureza e a sociedade como duas esferas distintas e perfeitamente separadas. Cada uma dessas esferas, portanto, tem as suas ciências e os seus cientistas, e não precisariam preocupar-se uma com a outra. Porém, segundo o autor, isso não passa de uma ilusão que criamos para nós mesmos, no intuito de justificar nossos pensamentos e nossas práticas.

Para Latour (1994), natureza e sociedade estão completamente misturadas e só é possível separá-las por meio da abstração. O que temos na prática - quando levamos em consideração uma instituição como a linguagem ou um ser vivo - são objetos híbridos (ou quase objetos), ou seja, naturais e sociais ao mesmo tempo.

Reais como a natureza, narrados como o discurso, coletivos como a sociedade, existências como o Ser, tais são os quase objetos que os modernos fizeram proliferar, e é assim que nos convém segui-los, tornando-nos simplesmente aquilo que jamais deixamos de ser, ou seja, não modernos (Latour, 1994:89).

Isso fica mais claro à medida que refletimos sobre os fatos científicos como constructos sociais. Por mais que um átomo possua uma parte apartada da cultura, que 
se comporta independentemente de nossa vontade, é somente por meio de nossa percepção (que inclui a cultura, as teorias científicas de uma época, os equipamentos de mensuração etc.) que podemos ver, compreender e significar qualquer coisa na natureza. Tudo carrega um arcabouço simbólico, que varia ao longo do tempo e entre diferentes culturas, ao mesmo tempo em que é natural.

Segundo Latour, existem dois processos que contribuem para a construção dos fatos científicos e das tecnologias. O primeiro - que o autor denomina "mediação" (ou "translação") - refere-se à construção de um fato científico ou de uma tecnologia. Para Latour (1994; 2000), a ciência se faz através de redes, que conectam pessoas, instituições e elementos não humanos. Para um fato ser aceito ou uma máquina funcionar, precisam estar amarrados a vários elementos (ou atores) humanos e não humanos. Quanto mais complexo for um fato ou uma máquina, mais complexa necessita ser essa rede, já que são demandados muitos apoios, financiamentos, laboratórios, pesquisadores etc.

Após um fato científico ou uma tecnologia ser construído e estabilizado, entra em cena um segundo processo, que Latour chama de "purificação", no qual os cientistas, ainda que sem admitir a si próprios, mas eficientemente, eliminam a trajetória (muitas vezes controvertida) da construção desses fatos; o que nos dá a impressão de que os povos modernos "descobrem" as coisas, sem a influência da sociedade.

A partir do momento em que levamos em conta tanto as práticas de mediação quanto as práticas de purificação, percebemos que nem bem os modernos separam os humanos dos não humanos nem bem os "outros" superpõem totalmente os signos e as coisas (Latour, 1994: 102).

Ao voltar sua atenção à prática científica e tecnológica, Latour (2000) cria o conceito de caixa-preta para ajudar a compreender a construção dos fatos científicos e máquinas sem precisar entender a fundo o conteúdo da ciência.

A expressão caixa-preta é usada em cibernética sempre que uma máquina ou um conjunto de comandos se revela complexo demais. Em seu lugar, é desenhada uma caixinha preta, a respeito da qual não é preciso saber nada, senão o que nela entra e o que dela sai (Latour, 2000: 14).

No caso do estudo da ciência ou engenharia, uma caixa-preta é uma discussão já encerrada ou máquina já construída. Quanto mais difundido e aceito for um fato científico ou uma máquina, mais fechada essa caixa está. E quanto mais aceito o fato pela comunidade científica, ou menos questionável, mais escura ela se tornará. Segundo o autor, o cientista da ciência precisaria então para entender o funcionamen- 
to da ciência simplesmente acompanhar o fechamento das caixas-pretas, enquanto elas ainda estiverem abertas.

Tome uma caixa-preta qualquer e congele a cena: você pode então considerar o sistema de alianças que ela une de duas formas diferentes. Em primeiro lugar, observando quem ela tem por finalidade alistar. Em segundo, considerando a que ela está ligada, a fim de tornar o alistamento inelutável. Por um lado, podemos traçar seu sociograma; por outro, o seu tecnograma (Latour, 2000: 229).

Não é necessário, portanto, ser um físico, por exemplo, para estudar a evolução da teoria da relatividade ou um engenheiro para estudar o funcionamento de um motor. É preciso acompanhar as controvérsias e as alianças, que sempre existem, durante o fechamento de uma caixa-preta. Isso nos possibilitará também mapear a rede que sustenta essa caixa-preta, já que para cada elemento no seu tecnograma há outro correspondente no sociograma. Nesse ponto, as redes ficam mais visíveis do que nunca, pois os cientistas estarão constantemente fazendo alianças com outros cientistas, instituições de pesquisa, de financiamento, com o governo etc., para tentar fazer com que os elementos não humanos necessários para o funcionamento sejam dominados e funcionem da maneira como desejam.

Para Michel Callon (1986), a tradução é um mecanismo de convergência entre os diversos elementos heterogêneos (humanos, não humanos, econômicos, políticos etc.) em uma rede sociotécnica. O autor considera esses elementos como atores, os quais estão interligados entre si por meio de elementos intermediários (textos, artefatos técnicos, pessoas, dinheiro etc.). Callon (1987) considera que os processos de tradução estão divididos em quatro etapas:

1. Processo de problematização: os atores buscam se tornar indispensáveis aos outros através da definição de problemas, e sugerem que estes sejam superados por meio de pontos obrigatórios de passagem.

2. Processo de atração: configura-se em uma série de processos através dos quais os atores buscam aprisionar outros atores em seus respectivos papéis propostos.

3. Processo de envolvimento: uma sucessão de estratégias a partir das quais os atores buscam definir e inter-relacionar os vários papéis que foram designados aos demais. Esse processo evita eventuais desacordos e possibilita a construção de um sistema de alianças estável.

4. Processo de mobilização: uma sequência de métodos usados pelos atores para garantir que o porta-voz por eles nomeado seja capaz de representar a coletividade, sem riscos de traição em período subsequente. 
É possível, portanto, não considerar apenas os movimentos que os atores realizam para atrair e controlar aliados para sustentar uma rede ao redor de um projeto, mas ainda dividir esse processo em fases.

Para se acompanhar e compreender a construção de um fato científico ou de uma tecnologia, basta então - segundo a Teoria Ator-Rede - acompanhar o fechamento de uma caixa-preta, com o cuidado de observar os movimentos de translação envolvidos entre os atores, o que levará a um mapeamento de seu tecnograma e de seu sociograma, ou da rede que sustenta essa caixa-preta, algo muito mais social e controverso do que aparenta ser no final do processo, quando tudo é considerado como dado e olvida-se o processo envolvido na construção dos fatos e das tecnologias. Na próxima seção discutiremos essas questões, especificamente em relação às pesquisas em células a combustível desenvolvidas no Brasil, suas redes de atores e as negociações decorrentes.

\section{Pesquisas em células a combustível no Brasil}

Em 2002, ainda durante o governo Fernando Henrique Cardoso, o Ministério de Ciência e Tecnologia, comandado por Ronaldo Mota Sardenberg, encomendou ao Centro de Gestão e Estudos Estratégicos (CGEE) uma prospecção para identificar as competências para o desenvolvimento de sistemas de células a combustível no Brasil. Concluiu-se que não havia uma instituição que pudesse desenvolver de forma isolada o projeto e que seria necessário estruturar um programa para isso.

Para tanto, definiu-se como necessário promover a coordenação das ações e projetos de cada instituição, estruturar um plano para recompor e compartilhar a infraestrutura de P\&D já instalada (MCT, PROCaC, 2002: 2).

Foi lançado, então, ainda em 2002 o Programa Brasileiro de Sistemas de Células a Combustível (PROCaC), programa do MCT voltado para a pesquisa em células a combustível, com o objetivo de organizar uma rede de pesquisas e promover ações integradas e cooperadas, que viabilizassem o desenvolvimento nacional da tecnologia de sistemas célula a combustível.

Em 2003, os países membros da Interntional Energy Agency (IEA) reuniram-se para discutir a formação de um grupo internacional para desenvolver programas de Pesquisa e Desenvolvimento (P\&D) e políticas estratégicas em tecnologias do hidrogênio. Ao final do encontro, foi criado o International Partnership for Hydrogen Economy (Iphe).

O Iphe consiste numa parceria internacional, formada por 17 países, incluindo o Brasil, para estimular políticas e pesquisas públicas e privadas para o desenvolvi- 
mento de tecnologias relacionadas ao uso energético do hidrogênio e à economia do hidrogênio, assim como seus regulamentos. Na época, quem chefiava a delegação brasileira e assinou o acordo foi a então ministra do Ministério de Minas e Energia (MME) Dilma Roussef. Em 2009 o Iphe mudou sua denominação para The International Partnership for Hydrogen and Fuel Cells in the Economy, para incluir também as células a combustível.

Depois da criação do PROCaC no final de 2002, não foi feito quase nada até 2005. Somente em 2005 foi liberado o primeiro montante de recursos significativos (R\$ dois milhões), através da Financiadora de Estudos e Projetos (Finep) (Matos, 2009).

Ainda em 2005, o MCT, sob o comando de Eduardo Campos, alterou o nome do programa para abranger também o hidrogênio, passando a chamar-se Programa de Ciência, Tecnologia e Inovação para a Economia do Hidrogênio (ProH2) (Rohrich, 2008: 109).

O programa também estruturou cinco redes em sua reformulação para tentar organizar as pesquisas:

1. Rede de células a combustível tipo membrana troca de prótons (PEM);

2. Rede de células a combustível de óxido sólido (SOFC);

3. Rede de combustíveis e hidrogênio;

4. Rede de integração e sistemas;

5. Rede de usuários.

Em 2004, após o encontro do IEA, o MME, começava a trabalhar no Roteiro para a estruturação da economia do hidrogênio no Brasil, como parte do acordo do Iphe, pelo qual cada país membro iria desenvolver o seu roteiro. O estudo foi lançado oficialmente em 2005 e tinha como principal objetivo a introdução da economia do hidrogênio no Brasil até 2025.

O MME tem por atribuição propor ao presidente da República as políticas nacionais e medidas para o setor energético, sendo o representante legal do Brasil para assuntos relativos à política do hidrogênio também no exterior. Assim é que o MME se responsabilizou pela organização e redação final do Roteiro para a estruturação da economia do hidrogênio no Brasil. Para tanto, fez uso da experiência prévia com o biodiesel e com o Programa Nacional de Introdução e Uso do Biodiesel, organizando o Roteiro à sua semeIhança (Rohrich, 2008: 111). 
No Brasil, atualmente, as pesquisas e desenvolvimento em CaC concentram-se principalmente em três áreas:

1. pesquisas em células a combustível de membrana condutora de prótons (PEMFC);

2. células a combustivel de óxido sólido (SOFC);

3. reforma do etanol para a produção de hidrogênio e catalisadores (CGEE, 2010).

Até 2007 , cerca de 290 projetos foram executados na área de pesquisa em células a combustível e hidrogênio com financiamento público, num total de cerca de R\$133 milhões (Matos, 2009). Existem também alguns poucos projetos de demonstração em andamento, como alguns ônibus movidos a hidrogênio rodando na cidade de São Paulo e um projeto da Universidade Federal do Rio de Janeiro (UFRJ) de colocar alguns ônibus movidos a hidrogênio em 2014 para a copa do mundo² no Brasil.

Na próxima seção, apresentaremos dados de uma pesquisa realizada junto ao Centro Nacional de Referência em Energia do Hidrogênio (Ceneh) com a intenção de apontar algumas das redes e articulações construídas em torno das células a combustível e sua consistência no cenário nacional.

\section{Centro Nacional de Referência em Energia do Hidrogênio (Ceneh): elo de uma rede em construção}

O Ceneh foi criado após a I Conferência Brasileira sobre o Hidrogênio, realizada no IV Encontro do Fórum Permanente de Energias Renováveis, em Pernambuco, onde se reuniram os cinco centros nacionais de referência em energias renováveis já existentes ${ }^{3}$. Em sua proposta, o objetivo principal apresentado pelo Ceneh era reunir e divulgar informações a respeito de pesquisas e desenvolvimento de tecnologias relacionadas ao uso energético do hidrogênio.

O Ceneh tornou-se assim um grande centro de informações, discussões e articulações de P\&D no setor de hidrogênio. Vários consórcios e pesquisas foram realizados, ao longo dos anos, por meio do Ceneh. O centro propriamente não realiza pesquisas, mas articula alianças com empresas e instituições que realizam. O principal aliado do Ceneh na realização de pesquisas é o Laboratório do Hidrogênio (LH2), instituição de pesquisa independente da Universidade Estadual de Campinas (Unicamp) e localizada no mesmo prédio.

Como veremos, o caso brasileiro tem algumas semelhanças com o caso do técnico em informática João, descrito por Latour (2000). Assim como no caso do técnico, a
2. "Ônibus brasileiro movido a hidrogênio começa a rodar em São Paulo", 08. Abr. 2009, disponível em: <http://www. inovacaotecnologica. com.br/ noticias/noticia. php?artigo=onibusbrasileiro-movido-ahidrogenio-comeca-arodar-em-sao-paulo>;

"Ônibus nacional que não polui usa hidrogênio como combustivel", 26 Maio 2010, disponível em: <http://g1.globo. com/rio-de-janeiro/ noticia/2010/05/ onibus-nacionalque-nao-polui-usahidrogenio-comocombustivel.html>. Acesso em: 14 Jan. 2010.

3. Os centros já existentes eram: Centro Brasileiro de Energia Eólica (CBEE), localizado na Universidade Federal de Pernambuco (Ufpe); Centro Brasileiro para o Desenvolvimento de Energia Solar Térmica (Green Solar), instalado na Pontifícia Universidade Católica de Minas Gerais (PUC-MG) Centro Nacional de Referência de Pequenas Centrais Hidroenergéticas (CERPCH), localizado na Escola Federal de Engenharia de Itajubá (Efei), em Minas Gerais; Centro de Pesquisas de Energia Elétrica (Cepel); e Centro de Referência em Biomassa (Cenbio), instalado na Universidade de São Paulo (USP). 
rede das células a combustível também é frágil e não se conseguiu, por ora, uma articulação sólida entre a pesquisa, o mercado e o governo.

O Ceneh pode ser visto como grande articulador de pesquisas e desenvolvimentos tecnológicos no uso energético do hidrogênio. Não desenvolve, como visto, diretamente qualquer pesquisa, mas possui várias alianças com instituições, entidades e empresas que desenvolvem.

O principal aliado do Ceneh no interior da rede é o LH2 da Unicamp. Criado em 1975, o laboratório foi instalado na Unicamp como unidade independente, com recursos e administração próprios. Na época, pesquisava-se a produção de hidrogênio e o seu uso de maneira eficiente em motores a combustão. O laboratório era ligado ao Instituto de Física, e seu responsável era o professor Ennio Peres da Silva (hoje também responsável pelo Ceneh). A maior parte dos recursos provinha de programas governamentais para substituição do petróleo. Vários laboratórios, como o LH2, foram criados pelo Brasil nessa época para a pesquisa de diversos combustíveis alternativos.

Porém, assim que a crise acabou e o preço do petróleo caiu, quase todos os projetos foram descontinuados, seus recursos cortados e a maior parte dos laboratórios simplesmente fechou. Todavia, o LH2 continuou. Sem recursos, demitiu praticamente todos os seus funcionários e técnicos, porém, através da infraestrutura instalada no período anterior, continuou subsistindo por meio da venda de hidrogênio para a indústria química.

O LH2 resistiu dessa forma durante muito tempo. Somente no fim da década de 1990 as coisas começaram a mudar. Após toda a discussão envolvendo problemas ambientais, várias medidas começaram a ser tomadas pelo mundo afora. A emissão de CO2, agora relacionada com o provável aquecimento global - que posteriormente foi medido pelo Painel Intergovernamental sobre Mudanças Climáticas (IPCC), instituto intergovernamental criado na ocasião - passou a ser uma preocupação séria da sociedade civil e de governos na maior parte do mundo. Esses problemas também foram levados em conta no Brasil.

No fim da década de 1990 a Finep propôs o financiamento de pesquisas e desenvolvimento de diversos combustíveis alternativos os combustíveis fósseis, incluindo o hidrogênio. Criou-se um grupo do hidrogênio e o LH2 voltou a receber recursos e novos técnicos puderam ser contratados. As pesquisas, que estavam paradas, puderam ser retomadas, agora sob a perspectiva da questão ambiental.

Em termos latourianos, pode-se dizer que houve uma reformulação dessas redes e o encontro de novos atores, governamentais e não governamentais. Por meio de con- 
sórcios firmados muitas vezes através do Ceneh, o LH2 desenvolve pesquisas relacionadas ao uso do hidrogênio com diversas empresas do setor energético como: Petrobrás, Companhia Paulista de Forca e Luz (CPFL), Centrais Elétricas do Norte do Brasil (Eletronorte), AES Tietê, Companhia Energética de Minas Gerais (Cemig), Empresa Metropolitana de Transportes Urbanos de São Paulo (EMTU), Companhia Hidro Elétrica do São Francisco (Chesf), Energética Barra Grande (Baesa). O Ceneh também presta serviços de consultoria a instituições ligadas a ministérios, como o próprio CGEE.

Os projetos desenvolvidos junto ao Ceneh tratam de pesquisas vinculadas ao uso energético do hidrogênio como: produção de hidrogênio, através de diversas fontes (hidrelétricas, etanol, biomassa, sistemas fotovoltaicos, sistemas eólicos); desenvolvimento de sistemas de células a combustivel; sistemas automotivos; baterias; redes energéticas; eficiência energética etc.

E como o Ceneh participou e interveio na configuração dessas redes direcionadas para as pesquisas do hidrogênio? Quais as condições para a consolidação e a manutenção dessas articulações sociotécnicas? Na próxima seção serão apresentadas e discutidas a formação e o enfraquecimento dessas redes.

\section{A fragilidade do hidrogênio nas redes brasileiras}

A constituição de uma rede sociotécnica depende de uma série de fatores e interesses convergentes. No caso do hidrogênio, a formação dessas redes tem enfrentado uma série de desafios e controvérsias.

O governo Fernando Henrique Cardoso apoiou as pesquisas em células a combustível em consonância com o restante do mundo na época, principalmente após George W. Bush assumir a presidência dos Estados Unidos, em 2001, e direcionar seu apoio às $\mathrm{CaC}$ nos automóveis elétricos, ao invés das tradicionais baterias. O programa brasileiro para a pesquisa em células a combustível (ProCac) só saiu em 2002, no final do mandato de FHC. O primeiro governo Lula ainda apoiou as pesquisas na área, fase em que foi liberada a maior quantidade de recursos financeiros.

Segundo os secretários do Ceneh, enquanto os Estados Unidos pretendiam utilizar fontes fósseis combinadas com o sequestro de carbono para produzir hidrogênio, o Roteiro para a Estruturação da Economia do Hidrogênio no Brasil, do MME (que faz parte dos programas do Iphe), previa utilizar as células eletrolíticas e o hidrogênio para viabilizar fontes de energia renováveis como a eólica e a solar.

Porém, as políticas voltadas para o hidrogênio e as $\mathrm{CaC}$ sofreram grande interrupção depois da posse de Obama, que deu novamente prioridade ao carro elétrico, já que 
Obama não está aliado à indústria de petróleo, como o era Bush. Consequentemente, as políticas no mundo todo, incluindo o Brasil, sofreram também com isso um grande desestímulo.

\begin{abstract}
Em maio de 2009, quando o Centro de Gestão e Estudos Estratégicos (CGEE) publicava um completo estudo sobre a Economia do Hidrogênio no Brasil, o presidente dos Estados Unidos, Barack Obama, anunciava um corte anual de US\$ 100 milhões em investimentos no desenvolvimento de carros movidos a hidrogênio. A decisão do governo norte-americano, na avaliação do assessor do CGEE, Demétrio Filho, irá gerar impactos nas pesquisas do setor no mundo todo. É difícil avaliar em um curto intervalo de tempo quais serão os impactos. A maior parte da pesquisa que está sendo realizada hoje é fruto de projetos que já estavam em andamento. Precisamos observar o que vai acontecer de agora em diante (CGEE, 2010).
\end{abstract}

A explicação oferecida pelos secretários do Ceneh indica que houve uma reaglutinação de interesses envolvendo diferentes atores, tanto humanos como não humanos.

\begin{abstract}
O sistema que o Bush tinha proposto que era o uso do hidrogênio veicular, com células a combustível, foi adiado no governo Obama, que preferiu apostar nas baterias. O que também não deu certo até agora. Os carros elétricos continuam com os mesmos problemas de sempre, que é baixa autonomia e tempo de carga das baterias muito elevado. E as baterias também não caíram de preço, exceto aquelas que os chineses estão fazendo. Então, a nossa expectativa aqui é que dentro de mais alguns anos eles vão ver que isso não deu certo e vão voltar pro carro a hidrogênio. E vai voltar. Só que parece que mais uns oito, dez anos vai ficar isso aí. As grandes montadoras só correram atrás do carro a hidrogênio depois que o Bush falou que queria o carro a hidrogênio (secretário Ceneh).
\end{abstract}

Esse tipo de controvérsia é recorrente e já foi explorada por Callon (1987). Em seu estudo, o autor fala sobre o desenvolvimento do veículo elétrico na França na década de 1970 e esse dilema já aparece. A Électricité de France (EDF) organizou um projeto para o desenvolvimento de um carro elétrico que utilizasse baterias recarregáveis ou células a combustíveis.

Fairly quickly, the catalyst refused to play their part in scenario prepared by EDF: Although cheap (unlike platinum), the catalyst had the unfortunate tendency of quickly becoming contaminated, rendering the fuel cell unusable. The mass market suddenly disappeared like a mirage. The VEL, recognized EDF's engineers, needed batteries whose performance was sufficient for the average users, 
and this sort of battery might be too expensive to produce for a long time to come (Callon, 1987: 90-91).

Nesse caso explorado por Callon, a tecnologia escolhida foi as células a combustivel, devido à vantagem do tempo de recarga ser muito menor (como o de abastecer um carro convencional).

No caso, os engenheiros aproveitaram as novas demandas de um público que já exigia mudanças em relação à poluição (do ar e sonora) dos carros convencionais para desenvolver um novo tipo de veículo. Sabiam que os carros grandes e potentes (inviáveis pela nova tecnologia baseada em células a combustível) eram um objeto de status e que estariam sacrificando esse lado em prol de outro aspecto nas demandas de um novo público consumidor. Procuraram, então, ajuda de ministérios para subsidiar os municípios interessados no carro elétrico e apoiaram mudanças nas regulamentações de níveis de poluição dos carros.

On the one hand, the motor vehicle was considered responsible for the air pollution and noise that plagues our cities; On the other hand, it was irretrievably linked to a consumer society in which the private car constituted a primordial element of status. However, electric propulsion would render the car commonplace by decreasing its performance and reducing it to a simple useful object. The electric car could lead to a new era in public transport in the hands of new social groups that were struggling to improve conditions in the city by means of science and technology (Callon, 1987: 85).

Logo de início, já vemos a presença de, além das usuais tecnologias (células a combustível, eletrodos, elétrons, catalisadores etc.), também de consumidores, movimentos sociais, ministérios etc. - elementos tão familiares aos sociólogos. O resultado dessa inovação seria desastroso se não houvesse apoio governamental, novas regulamentações, ou o público rejeitasse a nova tecnologia.

Porém, as coisas começaram a dar errado. Os elementos técnicos (catalisadores, células a combustível) não estavam respondendo adequadamente às expectativas. Os catalisadores estavam se contaminando, as células combustíveis não estavam se mostrando eficientes o suficiente, as baterias estavam se mostrando caras etc.

Além disso tudo, outros elementos (sociais ou humanos) não estavam mais se alinhando com os interesses da EDF. Os movimentos sociais perderam sua força tão rápido quanto surgiram. A insatisfação com a indústria automobilista revelou ser algo temporário. Outras soluções foram sendo pensadas e adotadas para resolver a poluição no transporte público (como motores a combustão mais eficientes). As novas demandas por um novo tipo de carro não foram suficientemente fortes para 
mudar as forças sociais existentes, que os carros tradicionais representavam (Callon, 1987: 91). A rede não adquiriu a coerência necessária para se desenvolver e se desfez com o tempo.

De volta ao caso aqui estudado, os secretários do Ceneh enfatizaram que o hidrogênio e suas tecnologias não foram totalmente abandonados. Mas os carros a bateria têm problemas grandes, como o peso dessas, o preço e o elevado tempo de recarga. Essas dificuldades são problemas que, segundo eles, dificilmente serão superados.

\footnotetext{
Você percebe que eles não largaram totalmente. Você percebe que eles continuam a trabalhar nisso. Claro, menos. Diminuíram os investimentos. Mas eles estão vendo que esse negócio de bateria é furado. Porque quem é do ramo, quem entende, sabe que a possibilidade das baterias atenderem o que o governo americano quer é muito baixa (secretário Ceneh).
}

Assim como no caso do veículo elétrico na França, os atores envolvidos deixaram de configurar uma rede estável e bem alinhada. Mudanças na articulação política das instituições governamentais também colaboraram para o enfraquecimento das alianças. Enquanto a Finep gerenciava e financiava os projetos, as P\&D progrediam, pois tinham autonomia e apoio. No momento que isso passou para o MCT e se organizaram as redes formais através do PROCaC, as coisas começaram a deixar de funcionar adequadamente.

Enquanto a Finep financiava e coordenava os projetos, tudo estava andando muito bem, tínhamos até projetos de sistemas de $\mathrm{CaC}$ que superavam projetos no exterior (como o Vega 1). Porém, quando o MCT lançou o programa PROCaC e assumiu a coordenação dos projetos e estruturou as redes, tudo parou de andar. Ninguém mais recebia as verbas nos prazos combinados, o que desestimulava os pesquisadores e criou atrasos generalizados, já que um dependia do outro nesta rede. Não demorou muito até tudo parar (secretário do Ceneh).

As instituições de pesquisas envolvidas na rede construída não recebiam os recursos previstos e por isso não era possível cumprir os prazos. A cadeia de desenvolvimento projetada entre as diversas instituições no projeto não funcionava, pois uma dependia da outra e não se cumpriam os prazos. Logo pararam totalmente de receber recursos e tudo estacionou. Quando o projeto e a rede foram rearranjados no $\mathrm{PROH} 2$, foi liberado apenas mais algum montante, as coisas andaram um tempo e logo pararam novamente, devido aos mesmos motivos.

Esses problemas indicados pelo Ceneh na rede estruturada pelo MCT lembram os processos identificados por Callon (1987). Num primeiro momento, vários atores 
se mobilizaram junto à Finep e ao MCT para tentar garantir suas participações e parcelas do orçamento no programa que seria então inaugurado (processo de problematização).

Os desacordos que os secretários do Ceneh apontam indicam claramente os processos de atração e envolvimento. Porém, não vemos um acordo sólido entre os membros, o que apontaria para o desfecho desses processos, sem a mobilização necessária, quando os atores já se veriam como coletividade organizada e buscariam uma representação forte e confiável.

Através da revisão de documentos importantes (CGEE, 2010) e de entrevistas com o pessoal do Ceneh e empresários do setor, foi possível constatar os principais entraves tecnológicos e sociais nas pesquisas em células a combustível e hidrogênio.

Atualmente, há pouquíssimas normas referentes ao uso e funcionamento das células a combustível. Enquanto outros países já estão extremamente avançados nesse quesito (mesmo a Índia), no Brasil há falta de pessoal contratado para esse serviço, e ainda nem se traduziu totalmente as normas dos demais países para se usar como referência (CGEE, 2010). Esse problema atrapalha muito o desenvolvimento de céIulas a combustível pelas empresas brasileiras, já que enquanto não houver padrões definidos, não há garantia de uso e sucesso no futuro. Isso também é um indício de desarticulação entre o setor governamental e o de P\&D.

Há a necessidade do apoio aos programas de Tecnologia Industrial Básica (TIB), uma vez que o Brasil já está atingindo um maior patamar na área de hidrogênio, com a necessidade de maior desenvolvimento da pesquisa aplicada e das etapas seguintes, de demonstração e comercialização de bens ligados ao hidrogênio energético. Isso ocorreria com um suporte maior à cadeia "metrologia, normalização, regulamentação técnica e avaliação da conformidade", estando incluído também o aumento da confiabilidade metrológica nas medições em sistemas de células a combustível (CGEE, 2010: 17).

Essa desarticulação entre os atores não se restringe à área das células a combustível. Segundo os pesquisadores entrevistados, parcerias entre as universidades e as empresas privadas são pouquíssimas até o momento. Como não há um mercado ainda para as células de combustível ou qualquer incentivo fiscal para o seu desenvolvimento, as empresas geralmente não se arriscam nesse tipo de inovação.

Algumas das poucas parcerias que se concretizaram até o momento foram estabelecidas entre as universidades e algumas distribuidoras de energia, mas, somente devido à regulamentação de P\&D da Agência Nacional de Energia Elétrica (Aneel) 
(Resolução n.o 242, da Aneel, de 1998) que obriga as empresas do setor elétrico a aplicarem pelo menos $1 \%$ de seus lucros em P\&D para a eficiência e conservação energética, e isso em pesquisas muito específicas para as empresas, que só ajudam a universidade com a verba que transferem.

Porém, algumas empresas do setor, como a Hytron (spin-off do Ceneh), saíram da universidade. Seus fundadores eram antigos pesquisadores do LH2 e hoje compartilham alguns projetos de pesquisa. Porém, ainda são pouquíssimas as empresas e as alianças desse tipo.

\begin{abstract}
A realização de projetos de demonstração tem como intuito a disseminação de informações relacionadas às tecnologias do hidrogênio ao público-alvo leigo. A integração de empresas às instituições de pesquisa no desenvolvimento dos projetos de demonstração deve ser um requisito para sua aprovação. Os recursos necessários à realização dos projetos podem ser oriundos dos Fundos Setoriais CT-Energ e CT-Petro, e projetos de P\&D Aneel (CGEE, 2010: 19).
\end{abstract}

Não há nenhuma linha de crédito especial para esse tipo de pesquisa, e o Banco Nacional de Desenvolvimento Econômico e Social (BNDES) cobra quesitos impossíveis de serem comprovados por uma empresa que está começando nesse mercado ainda quase inexistente, como comprovação de grandes lucros nos últimos cinco anos. Isso inviabiliza qualquer possibilidade de crédito especial e acaba sobrando apenas o capital de risco, com elevados juros.

É necessário, então, convocar outra licitação... Esse processo atrasa muito as pesquisas e, segundo os pesquisadores, muitas vezes as inviabilizam. Há, nesse caso, uma evidente desarticulação entre critérios legislativos, econômicos e científicos. É necessário adequar as leis para que haja harmonia para o desenvolvimento tecnológico dessa e de outras tecnologias que dependam parcialmente de equipamentos importados.

Toda construção de um fato científico ou desenvolvimento de alguma tecnologia dá-se, necessariamente, por meio de redes heterogêneas. É impossível fazê-lo senão através de uma rede que envolva cientistas, programas políticos, mercado, sociedade civil etc. Nenhum laboratório moderno ou empresa dedicada ao desenvolvimento de novos produtos pode atuar só.

Essa rede que se forma naturalmente pode ser chamada de rede informal se comparada às redes formais estruturadas em um projeto governamental. São essas redes formais que os secretários do Ceneh criticam. 
Se você quiser que alguma coisa pare de funcionar, é só você formar uma rede. Você forma uma rede, como fizeram com o PRO$\mathrm{CaC}$, e as coisas param de andar. Ninguém mais faz nada, porque aquele outro não fez, um depende do outro numa rede, aí você não consegue fazer sua parte, atrasam os pagamentos, não pagam você também não faz ninguém mais faz nada. Ou faz muito pouco (Secretário do Ceneh).

Segundo os secretários do Ceneh, o ideal seria que as instituições de pesquisa voltassem a ter autonomia para funcionar, estruturando elas próprias suas redes de pesquisa. Segundo Latour, essa tendência a informalidade aparece como algo "natural" na ciência, de um modo tal que os grupos sejam capazes de se aglutinarem e de se dispersarem motivados por uma série de fatos diferentes e conjunturais.

Todos eles [os atores] sabem mais ou menos o que querem [...]. Os grupos alistados sabem que são um grupo; sabem aonde querem chegar; sabem se o caminho previsto está interrompido; sabem até que ponto estão dispostos a se afastar dele; sabem quando voltar para ele; finalmente, sabem quanto mérito deve caber aos que os ajudaram por algum tempo (Latour, 2000: 187).

E complementa:

Com o automatismo, grande número de elementos são levados a agir com unicidade. [...] tem-se uma caixa-preta quando muitos elementos são levados a atuar como um só (Latour, 2000: 217).

Com o modelo de gestão chamado de "Big Science", iniciado nos Estados Unidos após a Segunda Guerra Mundial, várias redes formais foram formadas e coordenadas pelos diferentes governos e construíram muitas tecnologias importantes. Evidentemente, não significa que isso não possa dar certo. O que se passa é que os próprios pesquisadores e analistas no Brasil veem atualmente essas redes formais como algo problemático. À medida que o tempo passa, a rede proposta no primeiro programa (PROCaC) e reformulada no seguinte (ProH2) foi perdendo força e nunca funcionou de forma adequada.

O coordenador das redes não tem força suficiente para dirigir as pesquisas em algum sentido ou concentrar os esforços em alguma área, devido à grande liberdade que os cientistas gozam para decidir o que pesquisar, segundo a própria estrutura da pesquisa científica no Brasil. Não há grandes centros de pesquisa públicos no país, e as universidades e os pesquisadores têm autonomia para decidirem onde dedicar seus esforços. A fragilidade da rede proposta pelo MCT no ProH2 é um indício dessa desarticulação entre o setor governamental e o de P\&D. 
Para os secretários do Ceneh, o mercado de hidrogênio, assim como os veículos movidos a hidrogênio com $\mathrm{CaC}$, devem se tornar uma realidade no Brasil, assim como no resto do mundo. O Brasil deve acompanhar os outros países nesse sentido, pois assim que começar a produção dos carros movidos a hidrogênio, que deve ocorrer muito brevemente, devido à evolução de sua eficiência (muito mais eficiente que um motor a combustão) e custo, o mercado rapidamente se movimenta e implementa todo o resto necessário - infraestrutura de produção, armazenamento, transporte, abastecimento - para suportar o novo paradigma.

Esse paradigma depende da concatenação de diversos elementos dispersos para que a rede se estabeleça. O hidrogênio precisa atravessar todo um processo seguido por outros artefatos, como a gasolina, por exemplo.

\footnotetext{
Neste ponto uma comparação faz-se útil. Imagine os tempos iniciais da invenção do automóvel. Não havia infraestrutura para a rolagem dos automóveis, que tinha, por sua vez, preços proibitivos. A gasolina não era nem abundante nem barata e tampouco se encontrava em cada esquina. Pois bem, aproximadamente cem anos depois, o automóvel tornou-se accessível, existem estradas para sua rolagem e pode-se abastecê-lo em qualquer lugar, ou seja, aprendemos a lidar com o combustivel e, com a produção em massa e o mercado, os preços caíram (Linardi, 2008).
}

Segundo os técnicos do Ceneh, com o hidrogênio deve acontecer a mesma coisa. Já existem equipamentos para a produção de hidrogênio purificado, são simples, e assim que começarem a aparecerem os veículos, devem surgir espontaneamente também toda a infraestrutura e os equipamentos necessários. Há, portanto, uma aposta dos agentes interessados em que essa tecnologia se estabilize, a despeito de todas as condições desfavoráveis que esses mesmos atores apontam.

Todos esses problemas nos revelam uma imensa desarticulação entre o setor governamental e o de pesquisas. Os atores relacionados às pesquisas não têm o apoio necessários dos atores políticos. Ao mesmo tempo, os atores relacionados a essa indústria do hidrogênio e de $\mathrm{CaC}$ são muito poucos, já que não encontram estímulos e um mercado adequado.

As leis não se encaixam e os modelos de P\&D propostos pelos ministérios não funcionam adequadamente devido a essa desarticulação e também a consequente fraqueza da coordenação dos diferentes projetos. 


\section{Conclusão}

Não é possível uma nova tecnologia ou inovação consolidar-se no mercado (ou se fechar uma caixa-preta) enquanto os elementos heterogêneos - técnicos e sociais, humanos e não humanos - de uma rede de atores não estiverem funcionando adequadamente, alinhados e em harmonia. Os elétrons devem fluir, assim como as verbas para a pesquisa; o catalisador deve funcionar tão bem quanto os regulamentos; um motor deve ser tão eficiente quanto acessível e atraente ao público consumidor. Não há mais espaço para análises puramente econômicas da inovação, que ignoram os elementos técnicos, nem puramente técnicas, que colocam os elementos sociais somente ao fim da analise ou como plano de fundo.

Os artefatos tecnológicos são produtos de uma imensa rede de atores, ou elementos heterogêneos, rede que inclui humanos (cientistas, empresários, patrocinadores, consumidores), não humanos (elementos físicos, químicos, máquinas, mecanismos, dispositivos etc.), mercado, governo, entre tantas variáveis mais. Nessa visão, os produtos da ciência são resultados de uma construção coletiva, cuja abrangência vai muito além dos laboratórios, levando em conta diversos fatores sociais que são considerados essenciais nessa pesquisa para descrever o sucesso ou o fracasso de uma tecnologia como a das $\mathrm{CaC}$, como políticas governamentais, alianças com a universidade e o setor privado, disputa de recursos etc.

Muitas vezes os programas e as políticas relacionados à P\&D em células a combustível sofrem descontinuidades devido a mudanças de ministros ou governos, não entrando com força na agenda governamental. Programas como o ProH2 do MCT e o Roteiro do MME são considerados fracos devido ao fato de os coordenadores não disporem de influência e de recursos suficientes para conduzirem e direcionarem essas linhas de pesquisas e desenvolvimento.

Pelo que pudemos constatar na pesquisa junto ao Ceneh, mais do que um problema de formulação e implementação de políticas, é possível afirmar que as pesquisas em células a combustível no Brasil têm enfrentado sérias dificuldades em se estabilizar enquanto rede duradoura e autossuficiente.

Os processos de translação nas pesquisas e desenvolvimento em células a combustível no Brasil não estão funcionando adequadamente, na maior parte das vezes. Por uma série de razões de ordem institucional, tributária, de cultura empresarial, de formação científica etc., ocorre uma grande desarticulação entre o setor governamental, empresarial e de P\&D em células a combustível. Essa desarticulação muitas vezes inviabiliza os processos de translação necessários ao fechamento das caixas-pretas. 
A política energética de um país depende de uma série de condicionantes institucionais, assim como de elementos dispersos pelas inúmeras redes que se processam na cena social. A importância da sociologia da ciência reside exatamente em identificar a importância dos agentes institucionais e dos outros elementos na configuração desses artefatos.

Abstract: This paper aims to analyze political and social dimensions of the researches conducted in fuel cells and energetic use of hydrogen in Brazil. The research is a case study on National Center of Reference in Hydrogen Energy (Ceneh), a public center that develops technological researches related to hydrogen and fuel cells. For theorical background we depart from Sociology of Science, specially Actor-Network Theory developed by Bruno Latour and Michel Callon, that helped us to identify actors involved in researches in this field, their actions and struggles, as well as the social and political scenario for fuel cells in national and international levels.

Keywords: fuel cells, hydrogen, Ceneh, sociology of science.

\section{Referências}

BLOOR, D. Conocimiento e imaginario social. Barcelona: Gedisa, 1998.

CALLON, M. Some elements of a sociology of translation: domestication of the scallops and the fisherman of St. Brieuc Bay. In: LAW, J. Power, action and belief: a new sociology of knowledge?, p. 196-223. London: Routledge, 1986.

CALLON, M. Society in the making: the study of technology as a tool for sociological analysis. The social construction of technological systems. London: The MIT Press, 1987.

CENTRO DE GESTÃO E ESTUdOS ESTRATÉGICOS (CGEE). Hidrogênio energético no Brasil. Subsídios para políticas de competitividade: 2010-2025, 2010.

LATOUR, B.; WOOLGAR, S. A vida de laboratório: a produção dos fatos científicos. Rio de Janeiro: Relume Dumará, 1997.

LATOUR, B. Ciência em ação: como seguir cientistas e engenheiros sociedade afora. São Paulo: Editora Unesp, 2000.

_. Jamais fomos modernos. Rio de Janeiro: Editora 34, 1994.

LINARDI, M. Hidrogênio e células a combustível. Economia \& Energia, Ano XI, n.66, Fev.- Mar. 2008

LORENZI, Bruno, R. Em busca de alternativas energéticas: estudo sobre as pesquisas em células combustíveis no Brasil. Dissertação (Mestrado) - Programa de Pós-Graduação em Ciência, Tecnologia e Sociedade, Universidade Federal de São Carlos, São Carlos, 2012. 
MATOS, M. Investimentos financeiros em projetos de célula a combustível e hidrogênio no Brasil. Campinas: Editora Unicamp, 2009.

MINISTÉRIO DA CIÊNCIA E TECNOLOGIA (MCT). Programa Brasileiro de Sistemas de Células a Combustível (PROCaC), 2002.

MINISTÉRIO DE MINAS E ENERGIA (MME). Balanço Energético Nacional (BEN), 2010. Disponível em: <https://ben.epe.gov.br/downloads/Relatorio_Final_ BEN_2010.pdf>. Acesso em: 24 Jan. 2011.

RIFKIN, J. A economia do hidrogênio. São Paulo: M. Books, 2003.

ROHRICH, S. Descarbonização do regime energético dominante: perspectivas para a economia do hidrogênio no Brasil. Campinas: Editora Unicamp, 2008.

SILVA, E. P. Introdução à economia do hidrogênio. Campinas: Editora Unicamp, 1991. 
